Research, Society and Development, v. 10, n. 5, e22510514896, 2021

(CC BY 4.0) | ISSN 2525-3409 | DOI: http://dx.doi.org/10.33448/rsd-v10i5.14896

\title{
Unusual Ludwig's angina in systemic disabled patient related with periodontal
}

\section{disease}

Angina de Ludwig incomum em paciente com deficiência sistêmica relacionada a doença periodontal

Inusual angina de Ludwig em paciente con discapacidad sistémica relacionado con enfermedad periodontal

Received: 04/10/2021 | Reviewed: 04/16/2021 |Accept: 04/19/2021 | Published: 05/04/2021

Henrique Hadad

ORCID: https://orcid.org/0000-0002-0459-5860

São Paulo State University, Brazil

E-mail: kawamata_lais@hotmail.com

Laís Kawamata de Jesus

ORCID: https://orcid.org/0000-0002-0459-5860

São Paulo State University, Brazil

E-mail: kawamata_lais@hotmail.com

Ana Flávia Piquera Santos

ORCID: https://orcid.org/0000-0001-7562-772X

São Paulo State University, Brazil

E-mail: anaflaviaps_06@hotmail.com

Luara Teixeira Colombo

ORCID: https://orcid.org/0000-0001-6261-6044

São Paulo State University, Brazil

E-mail: luara_colombo@hotmail.com

Nelson Padilha Silva

ORCID: https://orcid.org/0000-0001-7873-5080

São Paulo State University, Brazil

Email: nelsonpad@gmail.com

Letícia Gabriella de Souza Rodrigues

ORCID: https://orcid.org/0000-0002-1241-5487

São Paulo State University, Brazil

Email: leticiagsrodrigues@gmail.com

Kezia Barbosa Mendes

ORCID: https://orcid.org/0000-0003-4145-5557

São Paulo State University, Brazil

Email: kezia_mendes10@hotmail.com

Gabriel Mulinari dos Santos

ORCID: https://orcid.org/0000-0003-4489-6868

São Paulo State University, Brazil

E-mail: gabriel_mulinari@hotmail.com

Gustavo Augusto Grossi de Oliveira

ORCID: https://orcid.org/0000-0001-7539-3097

São Paulo State University, Brazil

E-mail: gustavo.grossi@yahoo.com.br

Everton Pontes Martins

ORCID: https://orcid.org/0000-0003-3863-4271

Head and Neck Surgery at Unimed Hospital, Brazil

E-mail: everton_pontes@hotmail.com

André Luiz da Silva Fabris

ORCID: https://orcid.org/0000-0002-1777-2125

São Paulo State University, Brazil

Email: andre.fabris@hotmail.com

Alessandra Marcondes Aranega

ORCID: https://orcid.org/0000-0001-5856-7972

São Paulo State University, Brazil

Email: alessandra.aranega@unesp.br

Ana Paula Farnezi Bassi

ORCID: https://orcid.org/0000-0002-0031-4953

São Paulo State University, Brazil

E-mail: ana.bassi@unesp.br 


\begin{abstract}
The Ludwig's angina is an infectious process involving submandibular, sublingual, and submental spaces bilaterally. They can rapidly progress to airway obstruction and hemodynamic instability. The most common cause of Ludwig's angina is apical dental infections, specifically involving the roots of second and third mandibular molars, which are contiguous to the submandibular space. Periodontal diseases are related with bone loss around dental roots and create a situation where the inflammatory drainage tends to assume a sulcular direction. The purpose of this article is to report a clinical patient with an unusual development of a periodontic-endodontic lesion leading to Ludwig's angina in patient whit diabetics, hypertension and chronic kidney disease. Thus, we can conclude that even if it is not common reports of angina associated with periodontal diseases we must attend to patient's correct care, initiating antibiotic therapy, maintenance of the airways, removal of infectious focus and control of comorbidities diseases.
\end{abstract}

Keywords: Infection control; Ludwig's angina; Periodontal diseases; Tooth extraction.

\title{
Resumo
}

A angina de Ludwig é um processo infeccioso que envolve os espaços submandibular, sublingual e submentoniano bilateralmente. Eles podem progredir rapidamente para obstrução das vias aéreas e instabilidade hemodinâmica. As causas mais comuns da angina de Ludwig são as infecções dentárias apicais, envolvendo especificamente as raízes do segundo e terceiro molares inferiores, que são próximos ao espaço submandibular. As doenças periodontais estão relacionadas à perda óssea ao redor das raízes dentárias e criam uma situação em que a drenagem inflamatória tende a assumir uma direção sulcular. O objetivo deste artigo é relatar um caso clínico com desenvolvimento incomum de lesão endodôntica-periodontal levando a angina de Ludwig em paciente com diabetes, hipertensão e doença renal crônica. Assim, podemos concluir que mesmo que não seja comum relatos de angina associada a doenças periodontais devemos atender aos cuidados corretos do paciente, iniciando antibioticoterapia, manutenção das vias aéreas, retirada de foco infeccioso e controle de doenças comorbidades.

Palavras-chave: Controle de infecções; Angina de Ludwig; Doenças periodontais; Extração dentária.

\section{Resumen}

La angina de Ludwig es un proceso infeccioso que involucra los espacios submandibular, sublingual y submentoniano bilateralmente. Pueden progresar rápidamente a obstrucción de las vías respiratorias e inestabilidad hemodinámica. La causa más común de angina de Ludwig son las infecciones dentales apicales, que involucran específicamente las raíces del segundo y tercer molar mandibular, que son contiguos al espacio submandibular. Las enfermedades periodontales están relacionadas con la pérdida ósea alrededor de las raíces dentales y crean una situación en la que el drenaje inflamatorio tiende a asumir una dirección sulcular. El propósito de este artículo es reportar un paciente clínico con un desarrollo inusual de una lesión periodoncia-endodóntica que conduce a la angina de Ludwig en un paciente con diabetes, hipertensión y enfermedad renal crónica. Así, podemos concluir que aunque no sea común los reportes de angina asociada a enfermedades periodontales debemos atender al correcto cuidado del paciente, iniciando antibioterapia, mantenimiento de las vías respiratorias, remoción de focos infecciosos y control de enfermedades comorbilidades.

Palabras clave: Control de infecciones; Angina de Ludwig; Enfermedades periodontales; Extracción dental. 


\section{Introduction}

Ludwig's angina is characterized as an infection originated in the buccal tissues with severe and quick spread to bilaterally submandibular, sublingual, and submental spaces (Candamourty, et al., 2012). Clinically it can be observed an elevation of mouth floor and tongue (Patterson, et al., 1982). The most common tooth involved in Ludwig's angina is the second mandibular molar, but the literature also points the third molar as a potential site (Kremer \& Blair, 2006). We must be aware of the patient's clinical condition of Ludwig's angina because an effective diagnosis, prescription of antibiotic therapy and surgical management, when necessary, are essential for the control of the condition (Botha, et al., 2015).

In early stage the patients need to be managed with constant observation and intravenous antibiotics. While in advanced stages is possible require surgical drain age to guarantee an adequate oxygenation (Parhiscar \& Har-El, 2001). The procedure for tracheostomy is widely discussed in the literature management of the airway, mainly in patients with deep neck space infection and peripharyngeal edema (Taub, et al., 2017; Costain \& Marrie, 2011).

Patients with early-stage Ludwig angina who were treated with intravenous antibiotics had a higher incidence of airway compromise compared to patients who underwent surgical decompression and intravenous antibiotics (Edetanlen \& Saheeb, 2018). This case report a severe submandibular cellulitis of a systemic involviment of a patient due periodontitis.

\section{Methodology}

This case reports the clinical case of a patient with unusual development of a periodontal-endodontic lesion that caused Ludwig's angina in a diabetic patient, hypertension and chronic kidney disease. It presents in a descriptive and qualitative way the surgical and diagnostic approach, emphasizing the importance that we must be careful to control this disease and eliminate the infectious focus. Especially in patients with comorbidities, as diabetes mellitus, requires a high level of suspicion for life potentials threatening complications.

\section{Case Presentation}

A 65 years-old male patient whit diabetics, hypertension and chronic kidney disease referred to the emergency room of Unimed of Araçatuba Hospital with a 2-day history of progressive difficulty of swallowing, odynophagia, dysphonia, trismus, extraoral swelling, and pain. Clinical examination presented large soft tissue swelling under mandible, extending bilaterally to the angles of the mandible and inferiorly to the hyoid bone. Intraoral exam was difficulted by trismus, even it was possible to note tongue elevation, bad hygiene conditions and purulent exudate associated to the left mandibular second molar.

Computed tomography confirmed a periodontic-endodontic lesion associated to the mandibular second molar in the coronal (Figure 1A) and sagittal (Figure 1B) sections. 
Research, Society and Development, v. 10, n. 5, e22510514896, 2021

(CC BY 4.0) | ISSN 2525-3409 | DOI: http://dx.doi.org/10.33448/rsd-v10i5.14896

Figure 1. Computed tomography: (A) Coronal section of computed tomographic scan. (B) Sagittal section of computed tomographic scan.

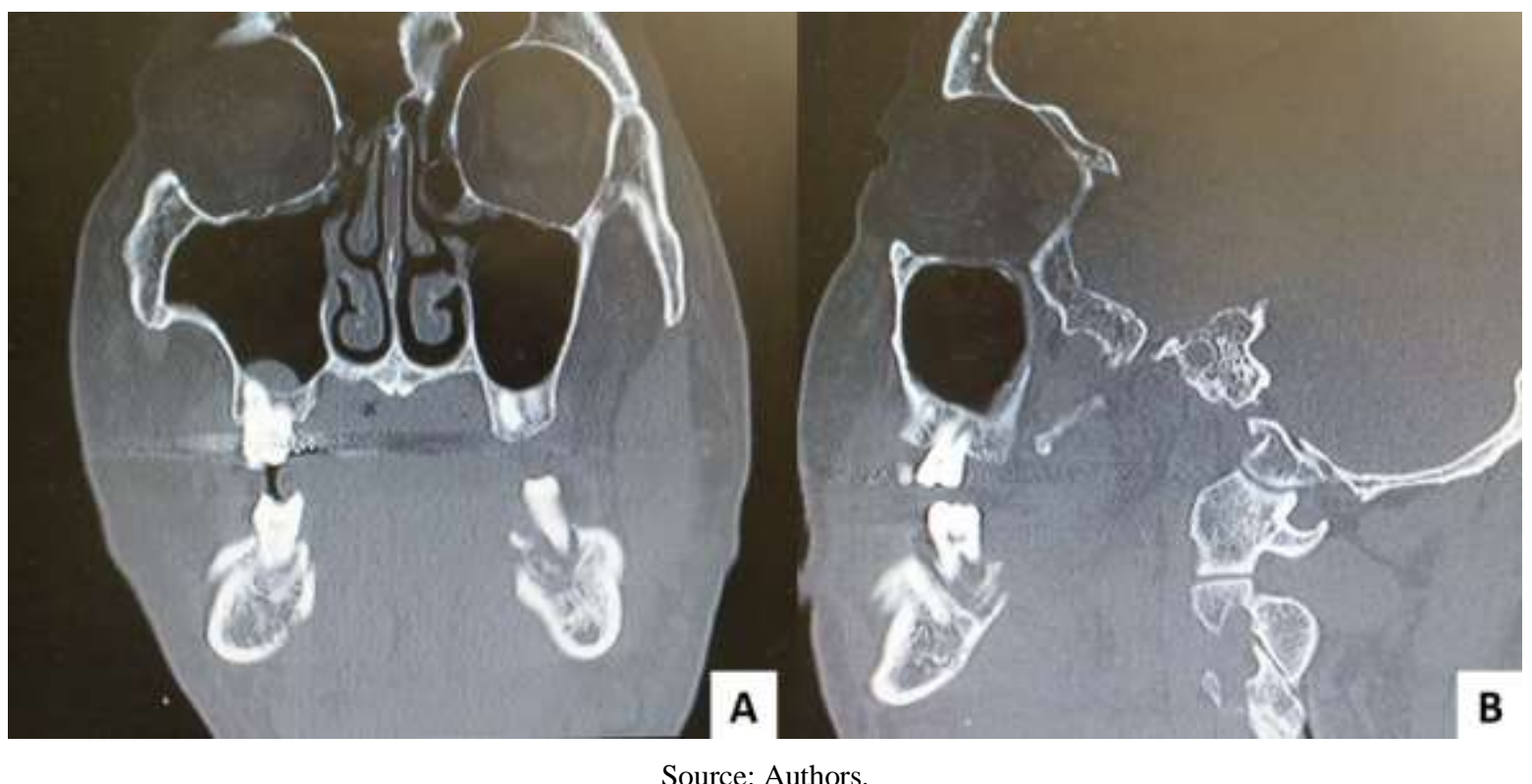

The patient advanced with a fast airway obstruction, and then tracheostomy was immediately performed. It was proposed a surgical treatment; the second mandibular molar on the left side was extracted and submental, sublingual and submandibular spaces were drained by means fistulation in three points following placement penrose drains (Figure 2).

Figure 2. Submental, sublingual and submandibular spaces drainage and placement penrose drains.

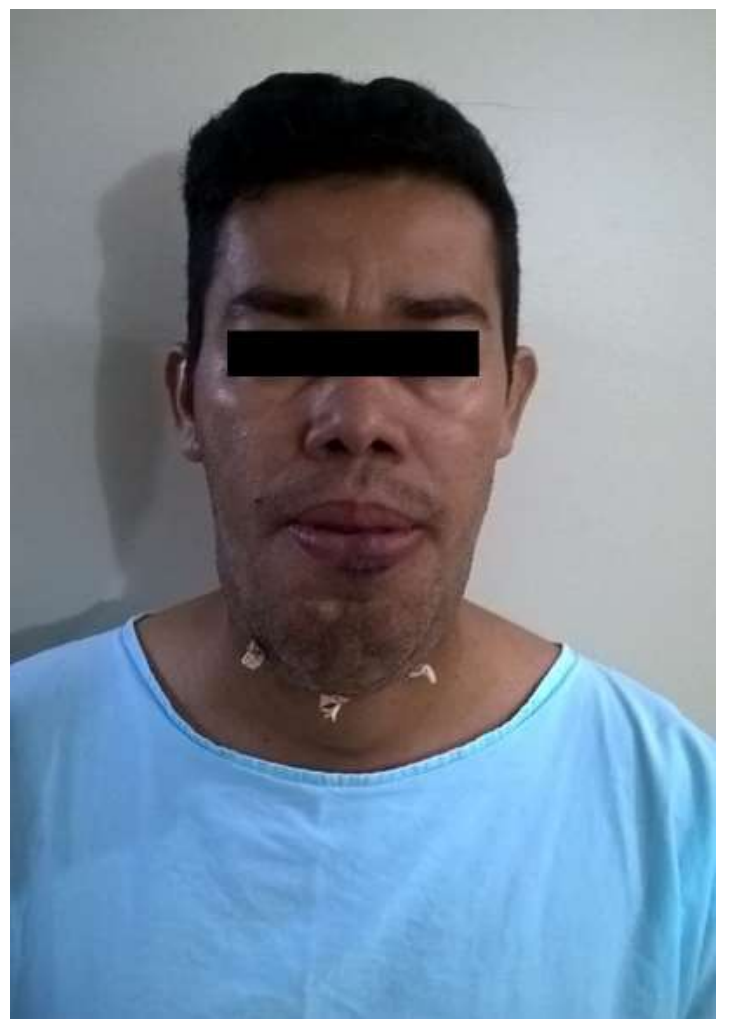

Source: Authors. 
Research, Society and Development, v. 10, n. 5, e22510514896, 2021

(CC BY 4.0) | ISSN 2525-3409 | DOI: http://dx.doi.org/10.33448/rsd-v10i5.14896

Antibiotic therapy with $1 \mathrm{~g}$ of ceftriaxone each 6 hours and 400mg of metronidazole each 12 hours was administrated intravenous.

One week after the patient presented a great decrease of facial asymmetry, trismus and fever. Postsurgical computed tomography showed a reduction of submandibular and sublingual swelling. The patient has been followed up for one year postoperatively with no further complication.

\section{Discussion}

The majority of Ludwig's angina occurs in patients with no comorbid disease (Botha, et al., 2015; Huang, et al., 2004). Patients related to diseases that compromise immunity and organic resistance, such as diabetes mellitus are more susceptible to the spread of an infection.

It's possible observe that the old age and the systemic diseases such as diabetes mellitus, which has a high prevalence (Kulkarni, et al., 2008; Genco, 1996) when associated with deep neck infections have a greater chance of complications, and it's necessary to give more attention to prevention of complications and even the possibility of death.

Immediate care may include traqueostomy (Parhiscar \& Har-El, 2001). Tracheostomy will be performed when there is an imminent possibility of airway obstruction (Taub, et al., 2017). It is important to treat Ludwig's angina in the earlier stages to increase the survival rate of the patient. The treatment protocol is surgery removal of the infection source, antibiotic therapy and airway maintenance (Costain \& Marrie, 2011; Rega, et al., 2006).

Most of these infections have as their etiology odontogenic causes (Kulkarni, et al., 2008; Boscolo-Rizzo \& Da Mosto, 2009), and when this infectious process is located below the apex of the teeth or below the mylohyoid muscle insert, the chance of a ludwig angina is greater. In immunosuppressed patients, we can find non-common evolutionary situations for Ludiwig's angina, such as periodontitis and endodontic lesion associated with periodontal lesion.

It is interesting to evidence the evolution of diseases that originated in patients with systemic alterations elucidating the treatment because odontogenic infections resulting from periodontal disease or periodontal-endodontic injury are rare. Although it is a rare case, it is important that the surgeon can identify the patient's condition and the associated comorbidities, to start the antibiotic treatment, and remove the cause and maintenance of the airways.

\section{Final Considerations}

Although the clinical presentation of angina with periodontic-endodontic lesion is rare, we must take care to control this disease and eliminate the infectious focus. Professionals should be aware that the clinical status in patients with comorbidities, especially diabetes mellitus, requires a high level of suspicion for potential life-threatening complications. In these patients oral health should be closely observed, a minor bacterial colonization may quickly and unexpectedly exacerbate into a fascial abscess.

\section{Acknowledgments}

The authors report no conflicts of interest related to this study.

\section{References}

Candamourty, R., Venkatachalam, S., Babu, M. R., \& Kumar, G. S. (2012). Ludwig's Angina - An emergency: A case report with literature review. Journal of natural science, biology, and medicine, 3(2), 206-208. 
Research, Society and Development, v. 10, n. 5, e22510514896, 2021

(CC BY 4.0) | ISSN 2525-3409 | DOI: http://dx.doi.org/10.33448/rsd-v10i5.14896

Patterson, H. C., Kelly, J. H., \& Strome, M. (1982). Ludwig's angina: an update. The Laryngoscope, 92(4), 370-378.

Kremer, M. J., \& Blair, T. (2006). Ludwig angina: forewarned is forearmed. AANA journal, 74(6), 445-451.

Botha, A., Jacobs, F., \& Postma, C. (2015). Retrospective analysis of etiology and comorbid diseases associated with Ludwig's Angina. Annals of maxillofacial surgery, 5(2), 168-173.

Parhiscar, A., \& Har-El, G. (2001). Deep neck abscess: a retrospective review of 210 cases. The Annals of otology, rhinology, and laryngology, 110(11), $1051-1054$.

Taub, D., Yampolsky, A., Diecidue, R., \& Gold, L. (2017). Controversies in the Management of Oral and Maxillofacial Infections. Oral and maxillofacial surgery clinics of North America, 29(4), 465-473.

Costain, N., \& Marrie, T. J. (2011). Ludwig's Angina. The American journal of medicine, 124(2), 115-117.

Edetanlen, B. E., \& Saheeb, B. D. (2018). Comparison of Outcomes in Conservative versus Surgical Treatments for Ludwig's Angina. Medical principles and practice: international journal of the Kuwait University, Health Science Centre, 27(4), 362-366.

Huang, T. T., Liu, T. C., Chen, P. R., Tseng, F. Y., Yeh, T. H., \& Chen, Y. S. (2004). Deep neck infection: analysis of 185 cases. Head \& neck, 26(10), 854860 .

Kulkarni, A. H., Pai, S. D., Bhattarai, B., Rao, S. T., \& Ambareesha, M. (2008). Ludwig's angina and airway considerations: a case report. Cases journal, 1(1), 19.

Genco R. J. (1996). Current View of Risk Factors for Periodontal Diseases. Journal of periodontology, 67 Suppl 10S, $1041-1049$.

Rega, A. J., Aziz, S. R., \& Ziccardi, V. B. (2006). Microbiology and antibiotic sensitivities of head and neck space infections of odontogenic origin. Journal of oral and maxillofacial surgery: official journal of the American Association of Oral and Maxillofacial Surgeons, 64(9), 1377-1380.

Boscolo-Rizzo, P., \& Da Mosto, M. C. (2009). Submandibular space infection: a potentially lethal infection. International journal of infectious diseases: IJID: official publication of the International Society for Infectious Diseases, 13(3), 327-333. 